\title{
USED FRYING OIL BIODIESEL PRODUCTION: EXPERIMENTAL FACTORIAL DESIGN AND MULTIVARIATE ANALYSIS
}

Rosana de Cassia de Souza Schneider, Robson Mocellin, Marcos Moura da Trindade, Luciano Roni Silva Lara and Marco Flores Ferrão*

Departamento de Química e Física, Universidade de Santa Cruz do Sul, Santa cruz do Sul-RS, Brazil.

\author{
*E-mail:ferrao@unisc.br
}

\begin{abstract}
Biodiesel is derived from renewable sources and it significantly reduces atmospheric emissions. It can be obtained by several processes, such as alcoholysis. In this work, biodiesel was produced through alcoholysis of used frying oil from a catering business. An experimental factorial design was used and the reaction products were analyzed through gas chromatography (GC), horizontal attenuated total reflection Fourier transform infrared (HATR/FT-IR) spectroscopy and exploratory analysis with principal component analysis (PCA) and hierarchical cluster analysis (HCA). Under the conditions analyzed, a high degree of conversion to methyl ester was found. As shown by HATR/FT-IR, the maximum conversion was obtained when the experimental conditions had the temperature $\left(50\right.$ e $\left.60^{\circ} \mathrm{C}\right)$, largest catalyst concentration $(0,6$ e $1,2 \%)$ and a $1: 8$ molar proportion of oil to methanol. It was possible to discriminate, through chemometrics analysis, four groups in the proposed experimental factorial design and determine the better condition for biodiesel production from used frying oil.
\end{abstract}

Keywords: biodiesel, used frying oil, GC, HATR, chemometrics.

\section{Introduction}

Alcoholysis is the replacement of the alkyl group of an ester by another one through the interaction between the triacylglycerol of oils (or fats) and alcohol. With methanol, the reaction can be referred to as methanolysis. The methanolysis of vegetable oils for production of methyl esters occurs in the presence of catalyst. The catalyst can be basic, acidic, or enzymatic depending on the starter material and needed conditions [1-5].

For the transformation of frying oil and other oils with high free fatty acid content, acid catalysis is recommended [6-7]. In the present work, sodium methoxide was used as a catalyst. This is a high performance catalyst and prevents saponification as secondary reaction. On the other hand, with basic catalysts, the process is faster and the reaction conditions are moderated [8].

The general starter materials are seed oils such as sunflower [9], soybean, ricinus, and rapeseed [10] or animal fats [11]. Currently the use of waste oils and fats for biodiesel production is extensively studied [1, 12-14]. The use of waste oil is of great environmental importance, once it can reduce the impact caused by that oil discard and also by planting oleaginous. The oleaginous planted area might be smaller if there is a more integral exploitation of the extracted oil. Therefore we consider that the biodiesel production of frying oil is less impacting than the one of new oils, however, the used method for the conversion into ester should be optimized as well as analyzed with several analytical techniques.

Nevertheless, it is necessary to consider that the used frying oils have properties different from those ones of refined oils.
The high temperatures of cooking processes and the water from the food promote the hydrolysis of triglycerides and increase the free fatty acid content in the oil. Also, the stability of the mixtures and increasings in the peroxide value, the viscosity, iodine value, saponification value, and density are different when refined and crude oils are used. [14-17]

Wang et al. [18] have produced biodiesel from frying oil with high acid content using acid catalyst $\left(\mathrm{H}_{2} \mathrm{SO}_{4}\right)$, proportion of 10:1 between methanol and oil and presented an alternative method that consists in a two-step method: reaction catalyzed by ferric sulfate $(2.0 \%)$ and followed by alkali $(\mathrm{KOH})$ transesterification. The authors have showed advantages from alternative method of no acidic wastewater, high efficiency, low equipment cost, and easy recovery of catalyst compared with the limitations of acidic effluent. Likewise, other researchers have highlighted that with acid catalyst it is necessary higher temperature and longer reaction time $[2,11,16-17]$. When the frying oil presents low acid index it is possible to use the alkali catalysis [5].

In relation to biodiesel analysis, several physicalchemistry methods [19] such as gas chromatography [2, 20$21]$ and high performance liquid chromatography are used [22]. The analysis of biodiesel can also be accomplished by spectroscopy. Often, the spectroscopy is done in combination with multivariate data analysis [16, 21, 23-24].

Spectroscopic methods have been increasingly used to replace classic chemical ones. Infrared spectroscopy is one method that has had its use increased due to its low cost, shorter time of analysis, non-destructiveness, and requirement of small quantities of sample, in addition to accuracy and reliability when associated with chemometric 
methods [25-28]. Moreover, FT-IR coupled with horizontal attenuated total reflectance (HATR) accessory simplifies many of the sample handling problems commonly associated with infrared analysis, and it is readily amenable to routine quality control applications [9].

Many of the published papers were devoted to the measurement of reflected light from the samples using accessories for attenuated total reflection (ATR) [29-36]. HATR is a well-known technique that produces good quality and highly reproducible spectra when good contact is established between the sample and the internal reflectance element (IRE) [27-28].

In a recent work, chemometrics were used for quantification of biodiesel blends using principal component regression (PCR), partial least square (PLS) and neural network (NN) [37]. In addition to that, PCR and PLS regression were used to determine water and methanol in biodiesel samples with smaller validation and prediction errors [24].

In association with chemometric tools such as principal component analysis (PCA) or hierarchical cluster analysis (HCA) methods, vibrational spectroscopy provides both qualitative and quantitative information [38]. The advantage of using principal components scores from PCA is that such a method displays the clustering information of chemical species from multiple wavebands [39].

Spectroscopy analysis with pre-processing techniques for the application of principal component analysis (PCA) and hierarchical cluster analysis (HCA) were used in this study to evaluate the infrared spectra of biodiesel and the reaction conditions for biodiesel production with high conversion using experimental factorial design. The samples analyzed by HATR/FTIR with PCA or HCA were compared with the conversion degree determined by gas chromatography analysis.

\section{Materials and Methods}

\subsection{Chemicals}

Ethyl acetate, n-hexane, and dichloromethane were obtained from Merck (Germany) and used as received. All the chemicals were analytical reagent grade and used without any pretreatment. The methyl ester standards (all above $99 \%$ purity) for GC were palmitic (hexadecanoic acid), stearic (octadecanoic acid), oleic (cis-9-octadecenoic acid), linoleic acids (cis-9,cis-12-octadecadienoic acid) (Supelco, Bellefonte, PA), and methyl heptadecanoate (intern standard) (Sigma,USA). The catalyst sodium methoxide was donated by Basf (Germany). Silica gel from Vetec (RJ, Brazil) was used as an adsorbent. The used frying oil was donated by the catering business (Prato Feito S.A., Santa Cruz do Sul, RS) that supplies meals to the businesses of the region. The sample volume $(10 \mathrm{~L})$ was mixtured from 5 industrial frying pans and the sample consists on frying soybean oil. The oil's acid index was analyzed by Cd 3d-63 official methods of the American Oil Chemist's Society (AOCS) and the used frying oil presented a low acid index $\left(0.4 \mathrm{mg} \mathrm{NaOH} \mathrm{g}^{-1}\right)$.

\subsection{Biodiesel production}

The used frying oil $(50 \mathrm{~g})$, catalyst and methanol were placed in a round-bottomed flask equipped with a reflux condenser and a thermometer. After the reaction, the formed methyl esters were separated from the glycerol by settling for $3 \mathrm{~h}$ in separation funnel. The methyl esters were purified by successive rinses with distilled water and dried at $110^{\circ} \mathrm{C}$. The methanolysis was carried out in the conditions described in Factorial Experimental Design presented in Table 1. The transesterification experiment conditions were based on the necessity to use alcohol excess in reversible reactions.

\subsection{Gas Chromatography (GC)}

For the GC analysis, o clean up was accomplished with $100 \mathrm{mg}$ of the sample, in a glass column $(200 \mathrm{~mm} \mathrm{x}$ $5 \mathrm{~mm})$ with $0.5 \mathrm{~g}$ of silica (70-230mesh). The methyl ester elution was with $2 \mathrm{~mL}$ of the hexane-ethyl acetate (95-5). The extract was diluted until $5 \mathrm{~mL}$ of $\mathrm{n}$-hexane with $50 \mu \mathrm{L}$ of internal standard (I.S.) of $100 \mathrm{mg} \mathrm{L}^{-1}$.

The gas chromatograph was a Varian GC model 3300 (Kyoto, Japan) fitted with a flame ionization detector (FID). The column used was a ZB-5 polydimethyl siloxane fused silica open tubular column with $5 \%$ phenyl groups (30 $\mathrm{m} \times 0.25 \mathrm{~mm} \times 0.25 \mu \mathrm{m})$. The initial temperature was $80^{\circ} \mathrm{C}$ (0.2 min), increasing by $8^{\circ} \mathrm{C} \min ^{-1}$ to $140^{\circ} \mathrm{C}(2 \mathrm{~min})$, followed by a $8^{\circ} \mathrm{C} \mathrm{min}^{-1}$ increase to $270^{\circ} \mathrm{C}$, and maintained there for $2 \mathrm{~min}$. The injector was warmed to $250^{\circ} \mathrm{C}$, and the detector was set at $280^{\circ} \mathrm{C}$. The quantification was accomplished by intern standardization. Methyl heptadecanoate was the intern standard (I.S.) used.

\subsection{Spectroscopic analysis}

A Nicolet Magna 550 FTIR spectrophotometer with a $4 \mathrm{~cm}-1$ resolution and 32 scans was used for the measurement of biodiesel samples as obtained. The triplicate spectra were recorded by applying the biodiesel sample on the surface of a Pike horizontal attenuated total reflectance (HATR) sample-handling accessory with ZnSe crystal.

\subsection{Multivariate analysis}

Spectra data were treated with multiplicative scattered correction (MSC) technique before a further multivariate analysis.

Data treatment in Pirouette $\AA 3.11$ software by Infometrix was carried out through the principal component analysis (PCA) and hierarchical cluster analysis (HCA). The program was run on an IBM-compatible Intel Pentium 4 CPU $3.00 \mathrm{GHz}$ and 1 Gbytes RAM microcomputer. HATR/FTIR spectra of the 17 the biodiesel samples from used frying oil were treated.

\section{Results and Discussion}

\subsection{GC analysis}

The main compounds in the fatty acid methyl ester (FAME) of frying oil were: palmitic (C16:0); stearic (C18:0); oleic (C18:1) and linoleic (C18:2) esters. Through $\mathrm{GC}$, it was possible to obtain conversion results. The total 
methyl esters in each condition of the experimental factorial design were quantified, as shown in Table 1. In these analyses, it was necessary to accomplish the clean up for removal of the residual acylglycerols present in the reaction products and to avoid the errors in GC analysis.

It was possible to observe that with 1:8 proportions oil-methanol it occurs maximum conversion with smaller catalyst quantities and shorter temperature with $3 \mathrm{~h}$ of reaction. Similar results were obtained with larger temperature and quantities of catalyst. The experiments involving 1:4 (oil-methanol), 1,2\% wt of catalyst and $60^{\circ} \mathrm{C}$ of temperature had a good conversion but these values are not enough for biodiesel production.

The advantage of using less time and more catalyst is the possibility of obtaining lower production cost.

Table 1- Experimental factorial design of the methanolysis of the used frying oil with methanol and sodium methoxide as catalyst and the conversion results.

\begin{tabular}{|c|c|c|c|c|c|}
\hline 苛 & 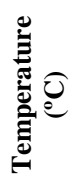 & 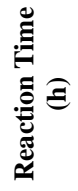 & 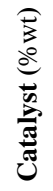 & 离总 & 章 \\
\hline 1 & 50 & 1 & 0.6 & $1: 4$ & 76 \\
\hline 2 & 60 & 1 & 0.6 & $1: 4$ & 48 \\
\hline 3 & 50 & 3 & 0.6 & $1: 4$ & 38 \\
\hline 4 & 60 & 3 & 0.6 & $1: 4$ & 62 \\
\hline 5 & 50 & 1 & 1.2 & $1: 4$ & 86 \\
\hline 6 & 60 & 1 & 1.2 & $1: 4$ & 93 \\
\hline 7 & 50 & 3 & 1.2 & $1: 4$ & 83 \\
\hline 8 & 60 & 3 & 1.2 & $1: 4$ & 83 \\
\hline 9 & 50 & 1 & 0.6 & $1: 8$ & 86 \\
\hline 10 & 60 & 1 & 0.6 & $1: 8$ & 79 \\
\hline 11 & 50 & 3 & 0.6 & $1: 8$ & 100 \\
\hline 12 & 60 & 3 & 0.6 & $1: 8$ & 83 \\
\hline 13 & 50 & 1 & 1.2 & $1: 8$ & 83 \\
\hline 14 & 60 & 1 & 1.2 & $1: 8$ & 90 \\
\hline 15 & 50 & 3 & 1.2 & $1: 8$ & 76 \\
\hline 16 & 60 & 3 & 1.2 & $1: 8$ & 100 \\
\hline 17 & 55 & 2 & 0.9 & $1: 6$ & 72 \\
\hline
\end{tabular}

\subsection{HATR/FTIR/PCA analysis}

The regions of the HATR/FTIR spectra with more important information were selected for multivariate analysis with PCA and HCA. The selected regions were within the ranges of $649-1,816 \mathrm{~cm}^{-1}$ and $2,788-3,037 \mathrm{~cm}^{-}$ 1 , as shown in Figure 1. In the spectral regions, there is chemical information from formed methyl esters and residual acylglycerols that did not transform during the methanolysis of the used frying oil [40].

The principal signals of the methyl esters were $v \mathrm{C}=\mathrm{O}$ in $1750-1725 \mathrm{~cm}^{-1}$ and $v O-C-C$ in $1160-1050 \mathrm{~cm}^{-1}$. The acylglycerols present similar signals but with small displacements that can be differentiated through the multivariate analysis technique.

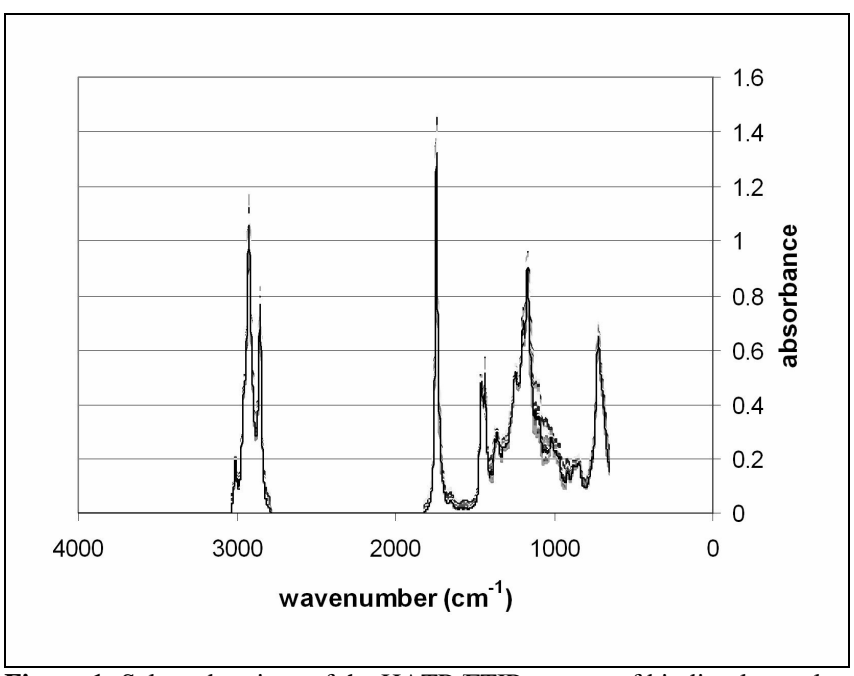

Figure 1- Selected regions of the HATR/FTIR spectra of biodiesel samples obtained through methanolysis of the used frying oil.

PCA was performed on the reflectance spectra of the 17 samples (51 spectrum) that were obtained in the reaction as experimental factorial design. Those analyses were done using the autoscaled spectral data, where each intensity value was subtracted by the intensity average value and divided by the standard deviation (Pirouette 3.11, 2006). After the preliminary analysis, the best conditions for data treatment were found and the principal components (PC) were calculated. Three outliers were detected and removed, they correspond respectively to spectrum 1, 3 and 44 .

With PCA it was possible to describe $85.8 \%$ of the data with two principal components which presented $73.3 \%$ and $12.6 \%$ of the total variance with the first and second principal components, respectively. Each calculated PC explains the individual contribution to the total variance.

The scores plot in Figure 2 shows four groups. The first group (A) contains the samples of lesser conversion as determined by gas chromatography.

When the reactions resulted in low conversion, the experiment had been performed with the least molar concentration of catalyst and the least methanol proportion as factorial experimental design.

The samples of group D that correspond to the major concentration of the catalyst and major methanol proportion were the ones that presented high conversion according to chromatography analysis results.

The experimental conditions used in groups B and $\mathrm{C}$ resulted in a similar conversion (Table 1), although the principal component two of scores graphic of the Figure 2, as well as dendrogram of the Figure 3 , have indicated that the groups have presented differences concerning to global composition. It is noteworthy that the group B experiments were accomplished with the largest quantity of the catalyst and the smallest proportion of methanol; such a situation leads to the existence of secondary reactions. It is suggested that secondary reactions have not occurred in the group $\mathrm{C}$ experiments. The products from secondary reactions are responsible for the separation of groups B and C. 


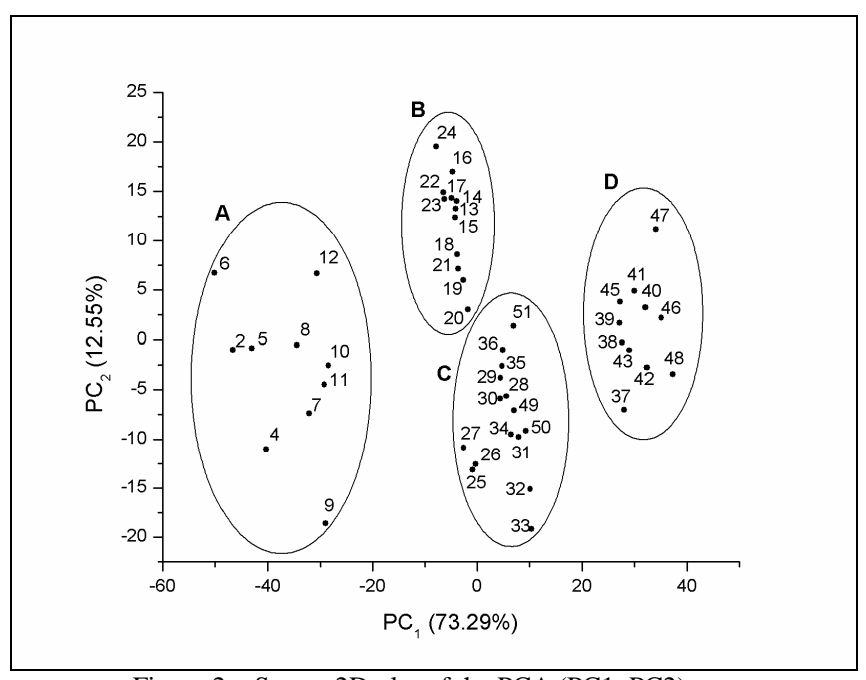

Figure 2 - Scores 2D plot of the PCA (PC1xPC2).

Similar reaction results were obtained in another work [41] with different experimental conditions using the same catalyst. Bournay et al [42] in the alcoholysis of pure sunflower oil, obtained yields of $96 \%$ using an oil/alcohol molar ratio of $1: 6$ and 0.5 wt $\%$ of the same catalyst. In that work, the formation of sodium soaps was prevented and the glycerin obtained was limpid and colorless. However, when these advantages are associated with a satisfactory experimental factorial design and a rapid analysis method, the results will be more important for the biodiesel industry because of the minor cost achieved and reduction of reaction time and analysis.

Likewise, the use of HATR/FTIR with multivariate analysis is an improvement upon previously obtained results in biodiesel production from pure vegetable oil or waste oil as the used frying oil. The use of HATR/FTIR with multivariate analysis allows for determination of which conditions among the different experiments present similar results, making it possible to rationally decide on biodiesel production based on the least cost and highest conversion.

In the experimental factorial design, other variables besides the quantities of catalyst and alcohol were studied. According to the PCA result, the temperature and reaction time were not determining factors in increasing the conversion degree of the used frying oil into biodiesel.

\subsection{HATR/FTIR/HCA analysis}

As mentioned above, the influence of the catalyst concentration and alcohol/oil molar ratio in biodiesel production allowed for the identification of four discriminated groups. The HCA confirmed the same four groups (Figure 3). Moreover, the dendrogram shows that the products formed in groups $\mathrm{B}, \mathrm{C}$, and $\mathrm{D}$ are more similar among themselves than to group $\mathrm{A}$. The greatest similarity was found between groups $\mathrm{B}$ and $\mathrm{C}$, confirming the same conversion degree.

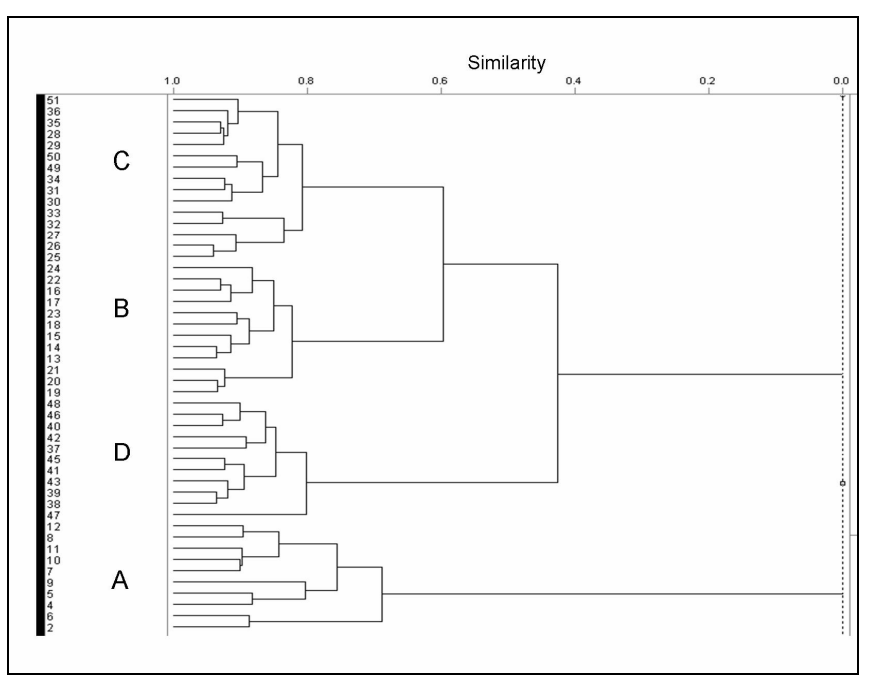

Figure 3 - HCA dendrogram of HATR/FTIR data of 17 products of used frying oil methanolysis in Table 1.

The HATR/FTIR/HCA developed for the chosen experimental factorial design proved that some experimental conditions are determining factors in reaching high conversion in biodiesel production by methanolysis of used frying oil.

\section{Conclusions}

During the last decade, many authors have used multivariate analysis to study the reactions using the signal from FTIR. This analysis method is rapid without requiring clean up, and it allows for the analysis of mixtures.

Based on the experimental factorial design conditions, it was possible to identify the determining variables for total conversion of the triacylglycerol of the used frying oil in methyl esters, as being the largest proportion oil-methanol (1:8), the least catalyst quantity $(0,6 \% \mathrm{wt})$, the lowest temperature $\left(50^{\circ} \mathrm{C}\right)$ and largest reaction time $(3 \mathrm{~h})$. With smaller proportion oil-methanol (1:4), larger catalyst quantity $(1,2 \% \mathrm{wt})$ and higher temperature $\left(60^{\circ} \mathrm{C}\right)$ it is also possible a high conversion, however, that conversion is not enough for the biodiesel production.

Through the experimental factorial design followed by HATR/FTIR using PCA or HCA, the experiments were grouped according to the different conversion degrees potentializing such technique in replacement of the GC one in the monitoring of new experiments conducted in a similar way. Besides that the results of multivariate analysis from spectrum of the final composition of each experiment confirmed the same performance for each planning studied.

However, although best conversion occurred in the conditions described above, the multivariate analysis showed that it is still possible to propose new experiments that explore time and temperature reduction aimed at minimizing cost.

For the used frying oil biodiesel production monitoring the association of the experimental factorial design with spectroscopy analysis (HATR/FTIR) followed by multivariate analysis (PCA or HCA) is a faster, non destructive alternative that can be implemented in on-line way. 


\section{Acknowledgements}

We thank the state agency Fundação de Amparo a Pesquisa do Estado do Rio Grande do Sul (FAPERGS) that provided a scholarship for L. R. S. L.; the Brazilian agency Financiadora de Estudos e Projetos (FINEP) for the general financial support provided; Basf for kindly donating the catalyst and FAP-UNISC by the scientific support.

\section{PRODUÇÃO DE BIODIESEL DE OLEO DE FRITURA USADO: PLANEJAMENTO EXPERIMENTAL E ANÁLISE MULTIVARIADA}

RESUMO: Biodiesel é derivado de fontes renováveis e reduz significativamente as emissões atmosféricas. Pode ser obtido de diversos processos, como a alcoolise. Neste trabalho, o biodiesel foi produzido através da alcoolise do óleo de fritura usado de indústrias de alimentação. Um planejamento experimental foi utilizado e os produtos de reação foram analisados por cromatografia gasosa (CG) espectroscopia na região do infravermelho com acessório de reflexão total atenuada horizontal (IV-HATR) e análise exploratória por análise de componentes principais (PCA) e análise hierárquica de grupos (HCA). De acordo com as condições analisadas obteve-se alta conversão em ésteres metílicos. Por IV-HATR, a conversão máxima foi observada em condições experimentais de temperatura $\left(50\right.$ e $\left.60^{\circ} \mathrm{C}\right)$, concentração de catalisador $(0,6$ e $1,2 \%)$ e a $1: 8$ de relação molar entre óleo e metanol. Também foi possível discriminar por análise quimiométrica, 4 grupos no planejamento experimental e determinar as melhores condições para a produção de biodiesel de óleo de fritura usado.

Palavras-chave: biodiesel, óleo de fritura usado, CG, HATR, quimiometria

\section{REFERENCES}

[1] Zheng, S., Kates, M., Dubé, M.A. and McLean, D.D., Biomass and Bioenergy, Vol. 30 (3), p. 267 - 272, 2006.

[2] Meher, L. C., Vidya Sagar, D. and Naik, S. N., Renewable and Sustainable Energy Reviews, Vol. 10 (3), p. 248-268, 2006.

[3] Marchetti, J. M., Miguel, V. U. and Errazu, A. F., Renewable and Sustainable Energy Reviews, Vol. 11 (6), p. 1300-1311, 2007.

[4] Shahid, E. M. and Jamal, Y., Renewable and Sustainable Energy Reviews, Vol. 12 (9), p. 2484-2494, 2008.

[5] Nye, M.J., Williamson, T.W., Deshpande, S., Schrader, J.H., Snively, W.H., Yurkerwich, T.P. and French, C.L. JAOCS, Vol. 60 (8), p. 1598$1601,1983$.

[6] Ramadhas, A.S., Jayaraj, S. and Muraleedharan, C., Fuel, Vol. 84 (4), p. 335-340, 2005.

[7] Freedman, B., Butterfield, R. O., and Pryde, E. H., JAOCS Vol. 63, p. $1375-1380,1986$.

[8] Vicente, G., Martínez, M., Aracil, J. and Esteban, A., Kinetics, Industrial \& Engineering Chemistry Research, Vol. 44 (15), p. 5447-5454, 2005 .

[9] Antolín, G., Tinaut, F.V., Briceño, Y., Castaño, V., Pérez, C. and Ramírez, A.I., Bioresource Technology, Vol. 83 (2), p. 111-114, 2002.
[10] Filippis, P., Borgianni, C. and Paolucci, M., Energy Fuels, Vol. 19 (6), p. $2225-2228,2005$.

[11] Ma, F., Clements, L. D. and Hanna, M. A., Biodiesel Fuel from Animal Fat. Industrial \& Engineering Chemistry Research, Vol. 37 (9), p. 3768-3771, 1998.

[12] Dorado, M. P., Ballesteros, E., Mittelbach, M. and López, F. J., Energy Fuels, Vol. 18 (5), p. 1457-1462, 2004.

[13] Wang, Y., Ou, S., Liu, P., Xue, F. and Tang, S., Journal of Molecular Catalysis A: Chemical, Vol. 252, p. 107-112, 2006.

[14] Tashtoush, G. M., Al-Widyan, M. I. and Al-Jarrah, M. M., Energy Conversion and Management, Vol. 45 (17), p. 2697-2711, 2004.

[15] Tomasevic, A.V. Siler-Marinkovic, S.S. Fuel Process. Technol. Vol. 81 , p. 1-6, 2003.

[16] Zhang, Y., Dubé, M.A., McLean, D.D. and Kates, M., Bioresource Technology, Vol. 89 (1), p. 1-16, 2003.

[17] Encinar, J. M., González, J. F. and Rodríguez-Reinares, A., Industrial \& Engineering Chemistry Research, Vol. 44 (15), p. 5491-5499, 2005.

[18] Knothe, G., JAOCS, Vol. 76, p. 795-800, 1999.

[19] Srivastava, A. and Prasad, R., Renewable and Sustainable Energy Reviews, Vol. 4 (2), p. 111-133, 2000.

[20] Mittelbach, M., Diesel Fuel Derived from Vegetable Oils, V[1], Chromatographia, Vol. 37 (11-12), p. 623-626, 1993.

[21] Knothe, G., Transactions of the ASAE 44 (2), p. 193-200, 2001.

[22] Trathnigg, B. and Mittelbach, M., Journal of Liquid Chromatography, Vol. 13 (1), p. 95-105, 1990.

[23] Felizardo, P., Correia, M. J. N., Raposo, I., Mendes, J.F., Berkemeier, R. and Bordado, J.M., Waste Manage, Vol. 26 (5), p. 487-494, 2006.

[24] Felizardo, P., Baptista, P., Menezes, J. C. and Correia, M. J. N., Analytica Chimica Acta, Vol. 595 (1-2), p. 107-113, 2007.

[25] Al-Alawi, A., van de Voort, F.R. and Sedman, J., JAOCS, Vol. 81, p. 441-446, 2004

[26] Russin, T.A., van de Voort, F.R. and Sedman, J., JAOCS, Vol. 81, p. 111-116, 2004

[27] Godoy, S.C., Ferrão, M.F. and Gerbase, A.E., JAOCS, Vol. 84, p. $503-$ $508,2007$.

[28] Ferrão, M.F., Godoy, S.C., Gerbase, A.E., Mello, C., Furtado, J.C., Petzhold, C.L. and Poppi, R.J., Analytica Chimica Acta, Vol. 595 (1-2), p. 114-119, 2007.

[29] Baeten, V. and Dardenne, P., Grasas y Aceites, Vol. 53 (1), p. 45-63, 2002.

[30] Sedman, J., van de Voort, F.R. and Ismail, A.A. JAOCS Vol. 77 (4), p. 399-403, 2000.

[31] Vogt, F., Karlowatz, M., Jakusch, M., Mizaikoff, B., Analyst, Vol. 128, p. 397-403, 2003.

[32] Iñón, F.A., Garrigues, J.M., Garrigues, S., Molina, A. and de la Guardiã, M. , Analytica Chimica Acta, Vol. 489 (1), p. 59-75, 2003.

[33] Christy, A.A. and Egeberg, P.K., Chemometrics and Intelligent Laboratory Systems, Vol. 82 (1-2), p. 130-136, 2006.

[34] Schulz, H., Baranska, M., Quilitzsch, R. and Schütze, W., Analyst, Vol. 129 (10), p. 917-920, 2004

[35] Fernández-Varela, R., Suárez-Rodríguez, D., Gómez-Carracedo, M. P., Andrade, J. M., Fernández, E., Muniategui, S., and Prada, D., Talanta, Vol. 68 (1), p. 116-125, 2005.

[36] Borin, A. and Poppi, R.J., Vibrational Spectroscopy, Vol. 37 (1), p. 27 $32,2005$.

[37] Oliveira, F.C.C., Brandão, C.R.R., Ramalho, H.F., da Costa, L.A.F., Suarez, P.A.Z. and Rubim, J.C., Analytica Chimica Acta, Vol. 587 (2), p. 194-199, 2007. 
[38] Bendini, A., Cerretani, L., Di Virgilio, F., Belloni, P., Lercker, G. and Toschi, T. G., European Journal of Lipid Science and Technology, Vol. 109 (5), p. 498-504, 2007.

[39] He, Y., Li, X. and Deng, X., Journal of Food Engineering, Vol. 79 (4), p. 1238-1242, 2007.

[40] Zagonel, G. F., Peralta-Zamora, P. and Ramos, L. P., Talanta, Vol. 63

(4), p. 1021-1025, 2004

[41] Encinar, J.M., González, J.F. and Rodríguez-Reinares, A., Fuel Processing Technology, Vol. 88 (5), p. 513-522, 2007.

[42] Bournay, L., Casanave, D., Delfort, B., Hillion, G. and Chodorge, J.A., Catalysis Today, Vol 106 (1-4), p. 190-192, 2005. 